\title{
Local and Long-Range Movements of Bald Eagles Associated with the Autumn Concentration in Glacier National Park, Montana
}

\section{Authors}

B. R. McClelland, L. S. Young, D. S. Shea, H. L. Allen, J. Crenshaw, and P. T. McClelland 


\title{
LOCAL AND LONG-RANGE MOVEMENTS OF BALD EAGLES ASSOCIATED WITH THE AUTUMN CONCENTRATION IN GLACIER NATIONAL PARK, MONTANA
}

\author{
B. R. McClelland \\ L. S. Young \\ D. S. Shea \\ H. L. Allen \\ J. Crenshaw \\ P. T. McClelland \\ School of Forestry \\ University of Montana
}

\section{Introduction}

A concentration of bald eagles (Haliaeetus leucocephalus) along lower McDonald Creek in Glacier National Park was first recorded in November 1939, when 37 were observed (Shea 1978). On that occasion and during each subsequent autumn, bald eagles have congregated to feed on spawning kokanee salmon (Oncorhynchus nerka). Kokanee is a non-native species, first introduced in the Flathead River drainage (in which McDonald Creek occurs) in 1916. Preliminary data suggest that there may be nearly 1,000 bald eagles now stopping at the Glacier concentration annually, although maximum counts are well below this level because of a high turnover rate.

The northern subspecies of the bald eagle was classified as endangered in February 1978 under the aegis of the Endangered Species Act of 1973 and subsequent amendments. This conveys a high level of responsibility upon managers of lands and waters used by bald eagles and demands a commitment to effective habitat management. The purpose of our research is to provide information essential to such management - knowledge of movement patterns, spatial and temporal distributions, numbers, and morhpology - directly benefiting not only Glacier National Park managers, but all public agencies, industrial corporations and private land owners responsible for bald eagle habitat.

This report summarizes the first part of the fourth year of a study of the ecology of Bald Eagles associated with the Glacier concentration. At this writing eagles are being tracked in the western states. Most data from this autumn have not yet been analyzed.

\section{Objectives}

Study objectives are:

1. To determine local movement patterns, migration routes, wintering 
sites, and nesting areas of bald eagles associated with the Glacier concentration.

2. To gather morphological data on captured eagles.

3. To monitor bald eagle numbers during the concentration.

4. To provide management recommendations for use in a coordinated regional plan for bald eagles.

\section{Methods}

Methods of censusing, capturing, banding, marking, and morphology characterization, were the same as those described in last years report. In addition, this year a blood sample was taken form each of 37 eagles. Ten cc were drawn from the bracheal vein. The Fish and Wildlife Service Patuxent Research Center will test samples for organochlorines, lead, and mercury.

During canoe counts, flushing distances of eagles were estimated and selected variables recorded. Behavioral responses to other disturbance events were recorded and will be evaluated as a basis for future study.

Radio-transmitters were placed on 14 eagles. The sample was stratified with respect to age class: 4 transmitters were placed on hatch-year eagles, 4 on 2-4 year old subadults, and 6 on adults 6 years or older.

Transmitter packages were attached dorsally or ventrally (7 each) to the two central rectrices, using a method modified from the procedures out lined by Dunstan (1973) and Kenward (1978) and used successfully in autumn 1979 (Young 1980). Tail-feather mounting provides a secure attachment platform, imposes minimal effect on the bird, and frees the bird of the transmitter package when the rectrices are molted.

Transmitter packages were constructed by Telonics, Inc. to project specifications. Total package weight is $56 \mathrm{~g}$, about $1 \%$ of the body weight of eagles at the concentration. This percent weight is below the $4 \%$ Dunstan (1973) and the 3.5\% Moss (Kenward 1978) observed with birds of prey carrying tailmount packages without apparent negative effects. Package dimensions are $1.8 \times 3.2 \times 4.3 \mathrm{~cm}$. Flared mounting brackets ( 8 degrees) maintain rectrices in a natural attitude.

Transmitters feature a mercury-activated tip switch which change the transmitter pulse rate depending on transmitter orientation (tai) position). When the tail (transmitter) is within 45 degrees of horizontal (e.g. flying), the transmitter fires in a fast pulse rate (75-85 per sec.). When the tail is at an angle greater than 45 degrees from horizontal (e.g. perching), the transmitter fires in a slow pulse rate (55-60 per sec.). This feature allows activity analysis. Projected operating life is 8-9 months. Transmitters operate in the $165 \mathrm{MHz}$ 
range. Transmitting antennae are constructed $0.11 \mathrm{~cm}$ diameter, flexible, polystrand, stainless steel wire. Transmitter range varies, depending on topography, vegetation, and relative positions of transmitter and receiver. Minimum range is $8 \mathrm{~km}$; maximum range is $95 \mathrm{~km}$.

Locally, eagles were tracked using $4 \mathrm{~dB}$ forward gain, hand-held and $9 \mathrm{~dB}$ antennas. Locations of transmitter-equipped eagles are determined by standard triangulation methods (Cochran and Lord 1963, Heezen and Tester 1967, Brander and Cochran 1969, Springer 1979, and others). Long-range tracking is being accomplished from vehicles and from aircraft with $4 \mathrm{~dB}$ forward gain, strut-mounted antennae integrated through an observer-operated antennae control unit. A Telonics programmerscanner with memory capability of 2000 frequencies and variable scanning speed (0.5-120 frequencies per min.) allows more than one transmitterequipped eagle to be simultaneously tracked from the air.

A stratified random sampling scheme was used to develop time budgets with representative coverage of sex, age class, and season and to allow tests for differences associated with these variables.

Long-range tracking will be continued through April.

\section{Results}

The 1980 autumn concentration of bald eagles was of short duration and, for the first time since 1976, fewer than 400 eagles were counted during the peak. Both occurrences resulted from a salmon run with a much below average number of $\mathrm{fish}$, all of which spawned and died over a very short time span. In most years there has been an abundance of dead fish well into December; in 1980 there were very few by the third week in November.

The maximum count of 377 (192 adults, 184 subadults, 1 unidentified) was made on 5 November, 1 to 3 weeks earlier than counts of other recent years.

Fifty-two bald eagles were captured in 1980; a total of 117 have been captured in the last 4 years. All 52 captured eagles were banded (standard aluminum leg band). Fourteen eagles were equipped with radiotransmitters. Bright orange patagials were placed only on those eagles which received transmitters.

Sightings of 24 eagles with markers form Glacier have given preliminary indications of long-range movements. Sightings have been made in Montana, Idaho, Oregon, Utah, Nevada, Colorado, and British Columbia. A hatch-year eagle marked in 1979 was shot near the Salmon River in Idaho, in winter 1980. A 3-year-old eagle marked in 1979 was caught in a coyote trap on the Madison River, Montana and was subsequently released following rehabilitation. An eagle marked as a 3-year-old in 1977 has been observed for three consecutive winters at Malheur National 
Wildlife Refuge, Burns, Oregon. An eagle marked in the San Luis Valley, Colorado in 1977, was seen frequently in Glacier during the autumn of 1980. This is the fourth fall it has passed through Glacier.

Following transmitter attachment, residency of eagles at Glacier National Park has ranged from 2 to 40 days. In 1980, the first eagle was equipped with a transmitter on 2 october and the last on 11 December.

Local movement, habitat use, and activity data are currently being analyzed. Most eagles left the McDonald Creek feeding area each evening to roost in 1 of 3 major communal roost sites. All 3 sites are located in old-growth forest, 2 in western larch (Larix occidentalis) and 1 in black cottonwood (Populus trichocarpa). Eagles flying to roost sites were counted on a regular basis. On 27 November 1979, 424 eagles, 91\% of the weekly count, were observed flying toward a major roost north of Lake McDonald. There is apparent interchange among roost sites, individuals alternating roost sites on different nights. Counts suggest seasonal shifts in preference from one roost site to another. Occasionally, eagles roost in trees along McDonald Creek throughout the night. Roost departure and arrival times were variable, depending on weather conditions.

Following dispersal from Glacier, transmitter-equipped eagles moved in a generally southward direction. An adult female, departing on 5 December 1979, moved southward down the Flathead Valley to Flathead Lake, where she remained until 13 December, feeding in bays along the southeast shore of the Lake and roosting on the forested west slopes of the Mission Range. On 14 December, she crossed the Mission Range and moved northeastward to Swan Lake. She remained in the Swan Valley until 12 March 1980, feeding on the Lake until freeze-over and then on the Swan River south of the Lake and roosting on the forested western slopes of the Mission Range in riparian stands adjacent to the River. On 13 March, she moved back to the Flathead Valley and ranged on the Lake and on the River north of the Lake until 29 March. She was observed perched in cottonwood trees along the river and larch away from the river. On 30 March, she moved northward onto the North Fork Flathead River, about $20 \mathrm{~km}$ south of the Canadian border. Due to insufficient funds, she could not be tracked farther; last contact on the North Fork was 3 April. On 6 April, a 5 year-old female that had left Glacier on 4 November 1979 was relocated east of the Continental Divide on the Two Medicine River. She ranged daily on grazing lands, feeding on ground squirrels (Spermophyllus columbianus) and using perch trees in nearby draws. Last contact was on the Two Medicine River $14 \mathrm{April.}$ It is assumed that both eagles continued north to summer ranges in Canada.

During late December 1980, 2 "Glacier" eagles near Vernon, Utah and 1 near Challis, Idaho were monitored daily. Migration "routes" from Glacier south to wintering areas are being identified. Tracking, including searching for other transmitter-equipped eagles, will continue 
through the winter.

During the 1981 spring migration we plan to track adult eagles to their Canadian nesting sites if additional funds are obtained.

\section{Literature Cited}

Brander, R. R., and W. W. Cochran. 1969. Radio-location telemetry. Pp. 95-103. In: Wildlife management techniques, 3rd ed. (R. H. Giles, Jr., ed.). Washington, D.C.: The Wild. Soc. 633 pp.

Cochran, W. W., and R. D. Lord, Jr. 1963. A radio-tracking system for wild animals. J. Wildl. Manage., 27:9-24.

Dunstan, T. C. 1973. A tail feather package for radio-tagging raptorial birds. Inland Bird Band. News, 45:3-6.

Heezen, K. L., and J. R. Tester. 1967. Evaluation of radio-tracking by triangulation with special reference to deer movements. J. Wildl. Manage., 31:124-141.

Kenward, R. E. 1978. Radio-transmitters tail-mounted on hawks. Ornis Scandl, 9:220-223.

Shea, D. S. 1978. Bald eagle concentrations in Glacier National Park. West. Birds, 9:35-37.

Springer, J. T. 1979. Some sources of bias and sampling error in radio triangulation. J. Wildl. Manage., 43:926-935.

Young, L. S. 1980. Attachment methodology for high-density, rectrice-mount radio-transmitter packages. (in prep.).

\section{Acknowledgements}

Numerous individuals from the National Park Service in Glacier National Park, from other federal and state agencies, and the public provided invaluable assistance.

In addition to the National Park Service, support funds were received from the School of Forestry and the Montana Cooperative Wildlife Research Unit (both at the University of Montana), the Wildlife Management Institute, and The American Petroleum Institute. 